\title{
Ethnoveterinary Plants Used Against Horn Cancer or Broken Horn Disease Among Tribals of West Nimar, Madhya Pradesh
}

\author{
${ }^{1}$ Parashar Preeti and D. A. Dhale ${ }^{2 *}$ \\ ${ }^{1}$ Department of Botany, P. M. B. Gujarati Science College, Indore, (Madhya Pradesh) India. \\ ${ }^{2}$ PG Department of Botany, SSVPS's, L. K. Dr. P. R. Ghogrey Science College, Dhule-424005 (Maharashtra) India \\ *Corresponding Authors E-mail: drdattadhale@gmail.com
}

\begin{abstract}
West Nimaris the South Western region of Madhya Pradesh state in West Central India. The region lies south of the Vindhya Ranges and consists of two portions of the Narmada and Tapti river valleys separated by a section of the Satpurarange. Bhil, Bhilala, Gond, Nayika and Tadwi are dominant tribe of the region. They are dependent on plant based medium and other for recovery of their ailment. The purpose of these studies was to gather ethnoveterinary medicinal knowledge from the area's livestock owners. Traditional healers gathered data on ethnoveterinary medicines through verbal and informal interviews, followed by a well-structured questionnaire. The majority of plants are dicotyledons, with monocotyledons accounting for a small percentage of the total. The leaves are used the most, followed by roots, rhizome, stem, gum, whole plant, and fruits. In the treatment, dermal approaches are used. In many circumstances, plant products, such as sindoor (vermillion), and cow urine, are utilised to treat horn cancer or fractured horn.
\end{abstract}

KEYWORDS: Ethnoveterinary, Nimar, Khargone, Bhil, Bhilala, Gond, Nayika and Tadwi.

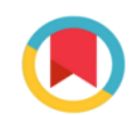

Check for updates
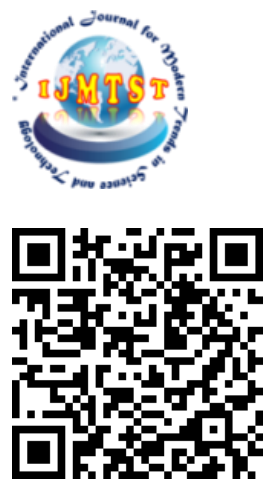

To Cite this Article:

DOI of the Article: https://doi.org/10.46501/IJMTST0707012

Available online at: http://www.ijmtst.com/vol7issue07.html

As per UGC guidelines an electronic bar code is provided to seure your paper

Parashar Preeti and D. A. Dhale. Ethnoveterinary Plants Used Against Horn Cancer or Broken Horn Disease Among Tribals of West Nimar Madhya Pradesh. International Journal for Modern Trends in Science and Technology 2021, 7, 0707033, pp. 68-71. https://doi.org/10.46501/IIMTST0707012

Article Info.

Received: 14 May 2021; Accepted: 2 July 2021; Published: 12 July 2021 


\section{INTRODUCTION}

Ethnoveterinary medicine is concerned with people's skills, knowledge, habits, methods and beliefs around the care of their pets. Early on, there was a lot of interest in recording and validating ethnoveterinary practises. Several research have been conducted since then, various reports have been written, and countless conferences and workshops have been convened. These actions have preserved ethnoveterinary knowledge from extinction: most ethnoveterinary knowledge was held by older community members who passed away. The introduction of new practises also made it more difficult for future generations to appreciate and utilise their forefathers' ideas and customs. Despite recent efforts to promote the application of ethnoveterinary knowledge throughout the world, much material is only documented in field reports and scientific articles [1, 2].

The history of Ethnoveterinary medicine is as old as the evolution of man on earth. As the human being has evolved on this earth, so as the traditional medicinal system has also evolved. The development of traditional Medicare system is no doubt related with the evolution of man $[3,4]$. Human and animal relationship was so close from the beginning. Menused animals for different purposes like food, hunting, transportation etc. So, they started domestication of animals for fulfilment of his various needs. Since the domestication of animals livestock keepers have been concerned about the health of their animals. So these people started innovating their own ways of keeping their animals healthy $[5,6]$. The ethnoveterinary medicines are often cheap and are best alternative to costly most of the allopathic drugs. The ethnoveterinary medicines provide cost effective drugs to poor farmers for their animals [7-9]. West Nimar, which is now divided into two districts of Khargone and Barwani in Madhya Pradesh state in West Central India, was originally known as West Nimar. The region lies south of the Vindhya range and consists of two portions ofthe Narmada and Tapti river valleys separated by a section of the Satpura range. There are 1407 villages in the district, which is divided into eight tehsils. About $40 \%$ of the population consists of tribal people. Bhil, Bhilala, Gond and Tadwi are mostcommon tribes. Tribals mostly rear cow, goats, buffaloes and bullocks as livestock.

\section{MATERIAL AND METHODS}

An ethnoveterinary survey was conducted in different tribal remote villages of the area during 2012-2016. The aim of these surveys was to collect ethnoveterinary medicinal information from the local cattle owners of the area. The data regarding ethnoveterinary medicines were collected by the traditional healers through verbal and informal interviews followed by a well-structured questionnaire. For this purpose, a number of elderly persons who have a good knowledge of traditional veterinary medicines were interviewed. The data are based on first-hand information gathered from the farmers and the livestock owners. The data were cross checked with more than one medicinal man. Commonly known as Bhumka, Badwas, Bhagat, Vaidya who have much knowledge on medicinal plants. Plants are collected with the help of local medicine men and identified with the help of flora [10-14].

\section{OBSERVATIONS}

\section{Abutilon indicum (L.) Sweet.}

Family: Malvaceae

Local name: Kanghi.

Useful plant part: Leaves.

Evt Uses: Decoction of leaves poured inside the hole of horn to cure horn cancer.

\section{Acacia nilotica Delile.}

Family: Mimosaceae

Local name: Black babool, Babul, Desi babool.

Useful plant part: Gum.

Evt Uses: Gum, Sindoor (Lead oxide) and Linum (Alsi) oil mixed together and applied over broken horn and bandaged it.

\section{Acanthospermum hispidum DC.}

Family: Compositae

Common name: Bada gokhru.

Useful plant part: Leaves.

Evt Uses: Leaf ash mixed with coconut oil applied around horns of animals suffering from worms.

\section{Aegle marmelos (L.) Correa.}

Family: Rutaceae

Common name: Bilawa patra, Bel patra.

Useful plant part: Fruits.

Evt Uses: Fruit pulp mixed with Sindoor (Vermillion) is applied on broken horn and bandaged it.

\section{Agave americana $\mathrm{L}$.}

Family: Asparagaceae 
Common name: Kamak cactus.

Useful plant part: Leaves.

Evt Uses: Paste of leaves is applied on body of animals to remove ectoparasites and bandaged on broken horns.

6. Asparagus racemosus Willd.

Family: Asparagaceae

Common name: Shatavari, Khargosh ki grass, Sevariya, Shatmul.

Useful plant part: Stems.

Evt Uses: Paste of stem is applied over broken horn of cattle for early healing.

\section{Curcuma longa $\mathrm{L}$.}

Family: Zinziberaceae

Common name: Haldi.

Useful plant part: Rhizome.

Evt Uses: Paste of rhizome and leaves of Azadirachta indica (Neem) is applied on the broken horn and bandaged.

\section{Cuscuta reflexa Roxb.}

Family: Convolvulaceae

Common name: Amarbel, Akash bel.

Useful plant part: Whole plant.

Evt Uses: Decoction of plant and paste of inflorescence of Mangifera indica (Mango) are boiled and poured into the hole created in horn in horn cancer.

\section{Desmodium oojeinensis (Roxb.) H.}

Family: Leguminosae

Common name: Tinas, Tiwas.

Useful plant part: Bark.

Evt Uses: Stem bark is pounded and mixed with cow's urine to form a paste. Broken horn is used to fill it, and hairs are used to bandage it.

\section{Dregea volubilis (L.f.) Benth ex Hook.f.}

Family: Apocynaceae

Common name: Harandodi.

Useful plant part: Leaves.

Evt Uses: Decoction of leaves is poured in horn to treat horn cancer

\section{Nicotiana tabacum $\mathrm{L}$.}

Family: Solanaceae

Common name: Tambakhu

Useful plant part: Leaves.

Evt Uses: Paste of leaves mixed with that of Momordica and Azadirachta indica applied on broken horn wounds in horn cancer.
RESULTS AND DISCUSSION: Horn is one of the important organ of cattle which is focusing the farmers for its beautiful look some time horn of cattle broken due to fighting with others animals or due to some other injury. One of the serious problem of cattle is also horn cancer. In India, cancerous growth of cattle horn is prevalent. It has a significant economic impact. A total 11 plants species belonging to 9 families and 11genera were used in treatment of broken horn (Fig. 2). Most of the plants are belongs to dicotyledons (73\%) while monocotyledons are relatively lesser percentage (27\%) (Fig. 1). Out of 11 species most of the plant parts are leaves and roots, rhizome, stem, gum, whole plant, fruits are used (Fig. 3). Dermal methodsare used in the treatment. In many cases not only single plant but plant products, sindoor (vermillion), cow urine are also used to cure horn cancer or in broken horn. Study indicates that tribals have sufficient knowledge about the therapeutic uses of plants. These methods can helps veterinarians, pharmacologists and pharmaceutical companies for inventing new drugs and further study.

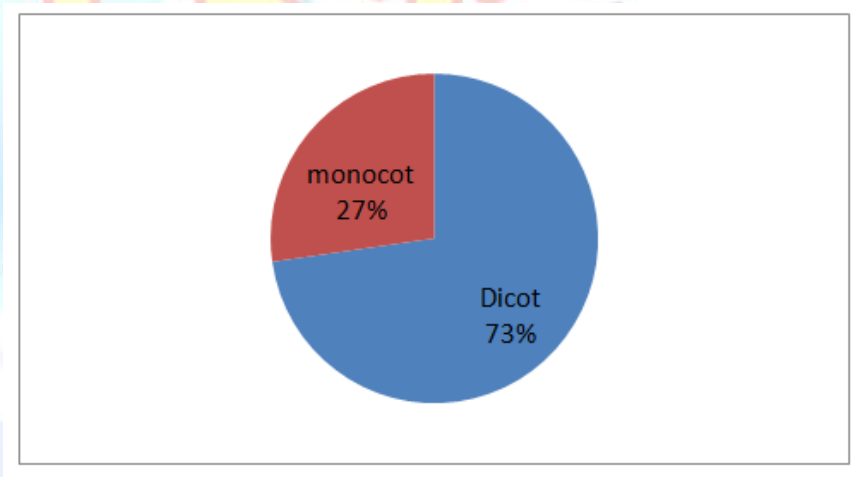

Fig. 1: Plant Group Used in Horn cancer

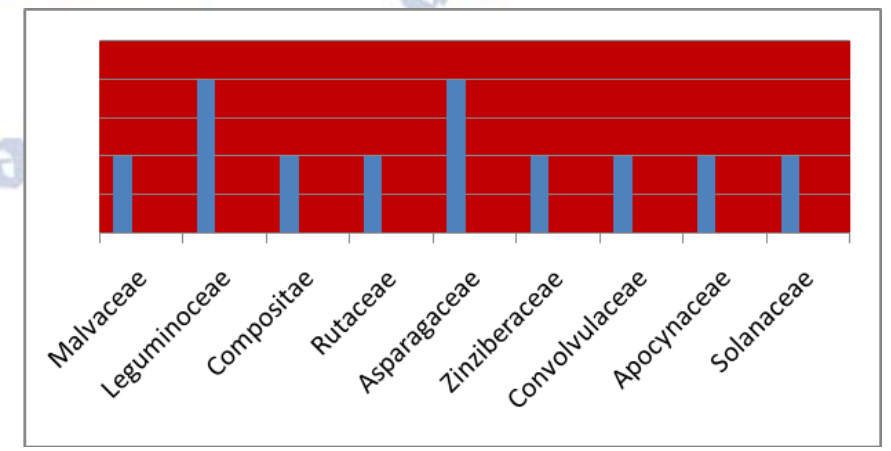

Fig. 2: Dominant Families for Treatment of Horn cancer 


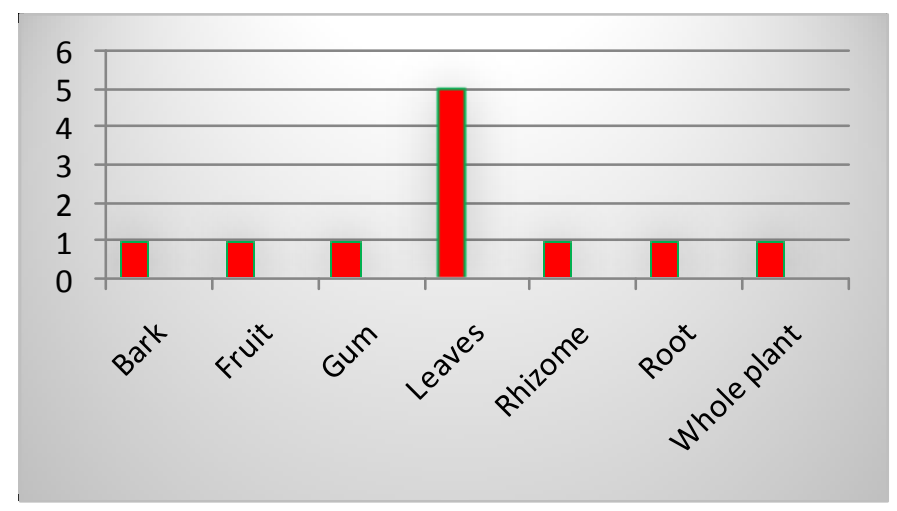

Herbarium Methods. Today and Tomorrow Printers and Publishers, New Delhi.

12. Mudgal, V., Khanna, K. K. and Hajara, P.K. (1977). Flora of Madhya Pradesh (BSI Publication, Calcutta, India)

13. Singh, K. K., Samanta, A. K., Maity, S. B., 2001. Nutritional evaluation of stylo (Stylosanthes hamata) hay in goats. Indian J. Anim. Nutr., 18 (1): 96-98

14. Anonyms. 2004. Identification and evaluation of medicinal plants for control of parasitic of livestock Technical report. CIRG, Makhdoom (Madhura)

Fig. 3: Plant Part Used in Treatment of Horn cancer

\section{REFERENCES}

1. Ngeh J. Toyang, Jacob Wanyama, Mopoi Nuwanyakpa andSali Django, 1999. Ethnoveterinary medicine. A practical approach to the treatment of cattle diseases in sub-SaharanAfrica. Macmillan Education Ltd and Bill Forse.

2. Anjaria J. V. 1984. Traditional (Indigenous) system of veterinary medicine for small farmers in India. FAO/UNO Bangkok report RAPA no. 80.

3. Nag A., P. Galav, P. and Katewa S. S. (2007). Indigenous anmal health care practices from Udaipur district, Rajasthan. Indian Journal of Traditional Knowledge Vol. 6(4) pp. 583 - 588.

4. Pranjale A. and Dube K. G. 2016. Ethnoveterinary traditional knowledge of some plants used in Wardha district (Maharashtra) International Journal of Science and Research. 5. pp. 1279-1282.

5. Udharwar S. V., V. D. Aher, G. U.Yadav, A. U. Bhikane and B.P.Dandge (2008) Study on Incidence, Predisposing factors, Symptomatology and Treatment of Horn cancer in Bovine with special reference to Surgery and Chemotherapy, Veterinary World, Vol. 1(1): 7-9

6. Bandyopadhyay, S. R. Sobham and Mukherjee, K. R. 2005. Ethnoveterinary medicine from Koch Bihar district, West Bengal. Indian Journal of Traditional Knowledge Vol. 4. pp. 456 - 461.

7. Baskarlingam. et al. 2015. A report on medicinal plants used in Ethnoveterinary practices of Toda tribe in the Nilgiris hills. Veterinary Science E Technology Vol. 6. pp. 1 6.

8. Chakraborty, S. and Pal, S. K. 2012. Plants for cattle Health: A review of ethnoveterinary herbs in Veterinary health care. 1(4): 144 - 152.

9. Mishra, S. 2010. Ethnobotany of Korku, Gond \&Nihal tribes of East Nimar, M.P. Ph.D.Thesis(Unpublished) D. A. $V$. V. Indore.

10. Hooker J. D., 1872-1897. "Flora of British India," Vol. I-VII, Reeve \& Co. Ltd., London.

11. Jain S. K. and R. R. Rao, 1977. A Handbook of Field and

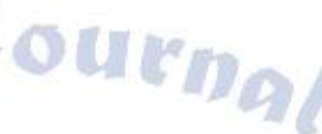

.

